\title{
Meanings of Poverty: An Ethnography of Bolsa Familia Beneficiaries in Rio de Janeiro/Brazil
}

\author{
Michele de Lavra Pinto
}

\section{INTRODUCTION}

The so-called Pink Tide that swept across the Latin American continent at the turn of the millennium took on different facets in different countries, although certain basic ideals remained as a common thread. The imperative of poverty reduction was one of them. In Brazil, the Bolsa Familia programme (hereafter, BFP) completed 14 years of existence in 2017. Its expansion to reaching over 13 million households in 2016 is an indication of the program's success in numerical terms. Yet so, the relative success of the program also testifies to the numerous obstacles and difficulties that remain with regards to overcoming the impacts of poverty in a country of such vast proportions and with such deep-rooted inequalities as Brazil. Indeed, the BFP also highlights that poverty is a complex and historical social phenomenon with multiple dimensions that cannot be measured by material benchmarks alone.

M. de Lavra Pinto $(\bowtie)$

ESPM (Escola Superior de Propaganda e Marketing),

Rio de Janeiro, Brazil

(C) The Author(s) 2018

M. Ystanes, I.Å. Strønen (eds.), The Social Life of Economic

Inequalities in Contemporary Latin America, Approaches to Social

Inequality and Difference, DOI 10.1007/978-3-319-61536-3_6 
This chapter presents the results of ethnographic research carried out between 2012 and 2015 with several families living in a favela (lowincome, informal neighbourhood $)^{1}$ in the southern zone (Zona Sul) of the city of Rio de Janeiro. The aim is to first describe key aspects related to the BFP (types of benefits paid and inclusion criteria in the programme) in order to subsequently unveil the meanings of "being poor" and "poverty" through the eyes of the beneficiaries, residents of the favela and the social workers managing the programme. Therefore, the study will show the kind of vision "the poor" have of themselves, their economic conditions and the social differences in their daily life in the favela. As is also illustrated by Costa's chapter (this volume), the BFP has not contributed to a radical redistribution of resources during Brazil's engagement with the Pink Tide. Now, as the Pink Tide unravels, Brazil remains one of the most unequal countries in the world. However, the ethnographic material presented here shows that BFP has made a significant difference in improving life conditions for the poorest segments of society. Even so, this study of how recipients conceptualise their situation and their identity is illustrative of the manners in which economic and social stratification, as well as multifaceted precariousness, remain fundamental features of life in Rio de Janeiro's favelas.

\section{The History of Welfare Programmes in Brazil}

There is an increasing number of studies in Brazil that discuss and analyse the effects of public policies, including conditional cash transfer programmes in education, health, work, and their impacts in eradicating poverty and/or reducing inequality in Brazil (see, e.g. Jaccoud 2006; Reis 2005; Sprandel 2004; Hoffman 2006). The studies are frequently based on quantitative data generated by the Pesquisa Nacional por Amostra de Domicilios Continua (Brazilian National Household Survey Continuos).

This interest is justified, since the issue of poverty is pointed out as a problem to be overcome by governments, especially in developing countries. Regarding the cash transfer programmes in Brazil, these policies have historically been presented as forms of social protection. The first discussion of a cash transfer programme in Brazil began in 1975, when the economist Antônio Maria da Silveira published the paper "Redistribution of income" with the objective of gradually eradicating poverty through government intervention (Silva et al. 2008, 93). The idea was based on a study of "negative income tax" by the North-American author Milton Friedman; a proposal that he endorsed in his book Capitalism and Freedom (1962). 
The Brazilian Constitution of 1988 states that "Social assistance shall be provided to those who need it, regardless of contributions to social security" (Brazilian Constitution of 1988, art. 203). Hence, the right to such policies and their benefits was formally assured to whomever may require them, regardless of any prior contribution. Under the new constitutional provisions, the social assistance policy began to organise its implementation under two pillars: the provision of services and the granting of monetary benefits" (IPEA 2010, 78). According to Silva et al. (2008), the context of widening social rights for social policies was instituted at an unfavourable moment from the point of view of the fiscal crisis of the State, which began in the 1980s and grew in the 1990s; when the implementation of neoliberal policies gained pace in Brazil. ${ }^{2}$ The neoliberal era in Brazil began in earnest with the election of Fernando Collor de Mello in 1989 (who was impeached on corruption charges and briefly replaced by Vice President Itamar Franco), and continued through Fernando Henrique Cardoso's two successive governments, from 1995 to 2002.

In 1995, the first year of Fernando Henrique Cardoso's presidency, the priority was to maintain economic stability and the Plan to Combat Hunger and Misery (Plano de Combate à Fome e a Miséria) from the previous government. This programme was then substituted by the Solidarity Community Programme (Comunidade Solidária) (Lahóz 2002). The Solidarity Community Programme aimed at articulating and linking the State with civil society, as well as implementing social programmes in the poorest municipalities of the country by integrating municipal-, state-, and federal governments. In 2001, during the second term of Fernando Henrique Cardoso, federal programmes with decentralised implementation in the municipalities were created (Silva et al. 2008, 98). According to Peres, "the Solidarity Community Programme survived to the end of the Fernando Henrique Cardoso government (2002). In January 2003 it became linked to the Ministry of Food Safety" (Peres 2005, 1). During 2003, the programme was gradually disarticulated and substituted by the Lula administration's Zero Hunger Programme (Programa Fome Zero).

Amongst the programmes developed under the umbrella of the Zero Hunger Programme, was a school allowance programme called School Stipend (Bolsa Escola). In order for each child or adolescent to be granted this fund, the parents or legal guardians of the child were required to present proof of the child's school attendance (at least 85 per cent), and to earn the minimum salary (established by the government) or less. The Gas Help (Auxilio Gás or Vale Gás) programme provided financial aids for purchasing 
cooking gas every two months to families that had a maximum income of half the minimum salary. This policy helped families that were already assisted by the Bolsa Escola and other programmes that integrated the Social Protection Network (Sistema de Proteção Social, integrating all the social programs). Additionally, it is also worth noting the Programa Bolsa Alimentação (Food Grant Programme), which was coordinated by the Ministry of Health (Ministério da Saúde) and carried out through the municipalities. The Bolsa Alimentação programme had a duration of six months, which could be prolonged for subsequent periods, provided that the beneficiary fulfilled health conditionalities (weighing and measuring small children in the household every month, following the vaccination calendar, pregnant women undergoing prenatal screening, etc.). The money from these programmes had a predetermined end (i.e. purchasing gas, food, and school material) and directing such funds to different products was prohibited. Therefore, in addition to the conditionalities, there was also a "control" of the expenditures of the benefit.

In 2003, in the early days of the government of then-President Luiz Inácio "Lula" da Silva, the unification process of national cash transfer programmes began to spread across several ministries. The unification process took place until 2007, when the transfer of the main programmes to the BFP was completed (Silva and Lima 2010). However, until the complete merger of the programmes, other social assistance processes were important for the unification and implantation of the BFP, among them the creation of the Ministry of Social Development and Fight against Hunger (Ministério do Desenvolvimento Sociale Combate à Fome) in 2004. According to Silva et al. (2008), starting in 2003 the federal government established qualitative and quantitative changes in the construction of a national policy of cash transfer. During four successive Workers' Party governments (President Luiz Inácio "Lula" da Silva [2003-2010]; President Dilma Rousseff [2011-2016 until the impeachment]), the BFP was not the most important in terms of the volume of resources invested, but it is said to have had the greatest impact on the lives of the poorest families (Weissheimer 2006). In political discourse, the programme became cast as an antithesis to the social policies and neoliberal matrix developed during the Fernando Henrique Cardoso government. When Luiz Inácio "Lula" da Silva was reelected for a second term in $2006,{ }^{3}$ his re-election was widely attributed to the success of these programs, as the majority of his voters came from the poorest part of the population. Nevertheless, and reflecting class based social cleavages in Brazil, the BFP was criticised by certain sectors of 
Brazilian society as something negative that encouraged the poor to not work and/or have more children.

Indeed, since its introduction, BFP has been the subject of extensive debate and controversy in the Brazilian media. Pires and Dias (2015) analysed how the BFP was represented in a large national newspaper (O Estado de São Paulo) in the period between 2003 and 2013. According to the authors, in 2003, the newspaper focused on the "escape mechanism" of the BFP and called it the "handout programme", since one of its characteristics was not setting a maximum time limit for receiving benefits. Such criticisms, over the years, cooled to the point where, in 2013, the main candidate of the opposition to the presidency proposed the constitutionalisation of the benefit, which was seen as a positive factor for the re-election campaign of then-president Dilma Rousseff (Pires and Dias 2015).

At the current political and economic moment in Brazil, characterised by budget cuts and political instability arising from the impeachment process against President Dilma Rousseff, the BFP is back on centre stage of public debate. Some advocate for its maintenance, while others regard it as a "handout programme" and "unemployment programme", and/or they support cuts in the programme budget, which in 2016 was around R 28 billion. However, it should be noted that my research was conducted at a time when this attention, although existent, was not as much in evidence.

\section{Bolsa Familia Programme: Benefits AND Eligibility CRiteria}

The BFP has been modified since its creation, although without losing the principle of cash transfer with conditionalities and autonomy of beneficiaries regarding the expenditure of money. Who then can request the benefit and which are the inclusion criteria? And what is the central measure of poverty deployed by the programme?

The main criterion established by the programme is per capita income. That is, a poverty line was established in which families with a monthly income per person between BRL 85.01 (EUR 25.24) and BRL 170.00 (EUR 50.48) $)^{4}$ may apply for the BFP. By establishing per capita income as the main criterion of inclusion and exclusion, the BFP seeks to reach the population that it considers to be poor and, therefore, in the most dire need of the benefit. This way, the programme anchors itself on a onedimensional poverty criterion, determining that the poor and extremely 
poor are included in the income range established by the programme. The programme registers other information about families such as the location of their residence, housing conditions, levels of education, and employment, but these features are not taken into account for assessing eligibility for the programme.

According to the Ministry of Social Development (Ministério de Desenvolvimento Social), ${ }^{5}$ the city of Rio de Janeiro, with a population of $6,476,631$ inhabitants (IBGE 2015), had a total of 479,693 families registered in the BFP in 2016. In February 2017, 233,766 families received the benefit, which represents a coverage of 79.7 per cent of the estimate of poor families in the municipality, with an average benefit in the amount of BRL 162.40 (EUR 48.22) (MDS 2017). ${ }^{6}$ In Copacabana and Ipanema, where the Pavão-Pavãozinho favelas are located, 3589 families were enrolled in 2015 and 1814 received the benefit. ${ }^{7}$ Here, data from the Reference Center for Social Assistance (Centro de Referência de Assistência Social, or CRAS) obtained by the researcher, lists approximately 265 families to be beneficiaries in 2016, of which 122 are in a situation of extreme poverty. According to CRAS's estimates, the most common profile for a beneficiary is a female between 30 and 39 years of age with an incomplete basic education, who has between two and four children, and who make a living through informal work.

The amount that each family recieves through the BFP varies, and is based on the profile registered in the Single Registration System (Cadastro Único) used by the programme. Among the information used for the calculus is the monthly income per person, the number of family members, household composition - the total number of children and adolescents up to the age of 17-, and the number of pregnant women. Although the financial aid received is not extensive, the families interviewed for this study consider it a "fixed" income that help them in numerous situations, for example to pay for electricity, public transport, food and rent, among other expenses.

The regulation of the programme establishes the following types of benefits: the Basic Benefit is granted only to extremely poor families (monthly income per person below or up to EUR 25.24). The Variable Benefit from 0 to 15 years amounts to EUR 11.58 and is granted to families with children or adolescents from 0 to 15 years of age. The Variable Benefit for Pregnant Women amounts to EUR 11.58 and is granted to families with pregnant women. Payment is made in nine consecutive instalments, provided that the pregnancy has been identified before the ninth month. ${ }^{8}$ Furthermore, the Nutritional Variable Benefit consists of EUR 11.58, and is granted to families with children between 0 and 6 months in their household. ${ }^{9}$ 
These benefits are limited to five per household. There is a variable grant for families with adolescents aged 16-17 consisting of EUR 11.36 (limited to two per household), and a special benefit for overcoming extreme poverty. The calculations differs from case to case, and is granted to households that are enrolled in the programme but remain in extreme poverty despite other benefits. This benefit is intended to boost families' income in order to overcome the extreme poverty threshold. As this outline of the programme's main features indicates, the amount of cash benefits recieved by individual households vary, but we should also add that in addition to the Bolsa Familia programme, the Unified Registry provides access to other governmental programmes and social policies at federal, state, and local levels. Such benefits are paid on monthly basis.

In order to receive the Bolsa Familia allowance, each recipient is given a debit magnetic-stripe card issued by the Federal Bank, Caixa Econômica Federal. It has the name of the recipient and the Social Identification Number (NIS) printed on it. For registration, it is necessary to present identity documents, proof or declaration of address, and proof of income. The NIS is a number assigned to every citizen seeking some kind of state assistance. Once the NIS is generated, the citizen, according to their income, is able to register for social programmes or make requests such as exemption from fees in civil service examinations, social tariffs for electricity bills, and so on. For the head of the household, it is necessary to present a social security number (CPF) or voter's registration card. For the other members of the family, any identification document, such as identity card, voter's registration card, birth or marriage certificate, $\mathrm{CPF},{ }^{10}$ or employment record card can be presented. The documentation must be submitted in one of the CRAS in the municipality where the applicant resides, which are responsible for identifying and registering families (MDS 2015).

In Rio de Janeiro, the CRAS are under the direction of the Municipal Social Welfare and Development Office (Secretaria Municipal de Desenvolvimento e Assistência Social, MSWDO). They are responsible for, among other things, directing families to town hall social services, which include several social programmes, such as Bolsa Familia. The CRAS are also under the direction of the Social Development Coordination (Coordenadoria de Desenvolvimento Social), whose competence includes participating in the planning of programmes and projects in their local area, implementing local social policy actions, conducting research, and coordinating, supervising, and evaluating the implementation of all the social development programmes and projects. The methods used to identify eligible households involve obtaining information from local people, schools, residents' association, trade unions, or from the families who apply for registration at the MSWDO themselves. 


\section{Conceptualisations of Poverty: Criteria and Definitions}

"Poverty" and "extreme poverty" are not new terms; however, they have been mentioned many times since the creation of the BFP. Both in research and in conditional cash transfer programmes in other context, "poverty" and "extreme poverty" are defined as conditions that need to be overcome. Thus, there is a significant generation of statistical data that attempt to identify and measure poverty rates (Neder 2006; Neri 2011). This reality based on figures is important and necessary; however, it also represents power because they may legitimise access and assistance in the area of public policies (Desrosieres 2010). Therefore, it is important to have in mind that no perspective on "the problem of poverty" is neutral. Rather, it remains an issue open to conflicts, struggles and disputes over how to define it, which terms to use, and how solutions are defined and implemented.

This is evident when we examine what the literature has to say about the indices used to measure poverty. Neri (2010) emphasises that there are some poverty measures taking several dimensions into regard, for example "sanitation" and "electricity", while other more simple measures focus on a single dimension-usually the income. In Latin American literature, for example, the concepts of Basic Needs Index and Human Poverty Index have frequently been used (Neri 2010). The Ministry of Social Development uses a synthetic indicator called the Family Development Index as a means of approaching the families that have-based on their income level-become enrolled in Bolsa Familia. The index is compiled from six aspects: vulnerability, access to knowledge and work, availability of resources, child development, and housing conditions.

For some authors, such as Rocha (2007), there is no "unambiguous" definition of poverty. The starting point for discussion on the issue should be a conceptual explanation, which depends on the standard of living and how basic human needs are met. According to Rocha, "to determine who is poor in a defined social group is to establish a common list of a minimum set of public services and goods necessary for survival" (Rocha 2007, 23). In the social science literatures, different forms of qualitative analysis have been employed to analyse poverty. DaMatta (1995) emphasises the importance of culture and history in the definition of poverty in Brazil. Studies of poverty elsewhere support this point; poverty is always conceptualised in particular ways depending on the social, cultural, and historical context (see, e.g. Anderson and Broch-Due 1999; Broch-Due and Schroeder 2000; Milton 2007; O'Connor 2002; Lautier 2002). 
On a global basis, the United Nations and the World Bank define a "poor" country based on income levels. On individual levels, the World Bank's international poverty line is currently USD 1.90 per day. Despite the advantage of simplicity, it is argued that, by focusing solely on income, we are also implicity framing the discussion about poverty to a question of purchasing power. Certainly, the level of income is relevant as it determines the purchasing power of consumers and whether they have enough to feed themselves. However, increases in income does not automatically translate into better access to basic services such as health and education, among others. Rego and Pinzani $(2013,149)$ emphasise that the problem of analysing poverty only based on income is that this criterion does not account for the level of well-being of individuals, making their definition and criteria inaccurate. There is ample scope for determining poverty criteria, thus creating the need for a multidimensional view of poverty and deprivation, as stated by Sen (2000).

Based on this perspective, a team of researchers of The Oxford Poverty and Human Development Initiative, with the support of the United Nations, created an indicator called "Multidimensional Poverty Index". This indicator, according to Rattner (2010), seeks to build a picture of poverty based on the fraction of households that lack basic goods and services (whether the house has a cement floor, a bathroom and electricity). Other questions seek to assess issues regarding education and health. Rattner (2010) also highlights that there is no unanimity as to results and how to determine poverty. A simple definition would be, "people who do not have enough to lead a dignified life" (Rattner 2010, 76). But what is "enough", which goods and services characterise it, and who should decide these questions - researchers, governments, or international agencies? My contention is that these are far more complex issues than what can be measured by numbers, and that the poor themselves should have the final word on their conditions and expectations on poverty.

\section{“Being Poor": Meanings and Perceptions IN THE FAVELA}

The implementation of public policies in the favelas is not something new in the history of Rio de Janeiro (see, e.g. Magalhães 2013). Valladares $(2000,2005)$ explains how favelas were introduced and treated in the political and social debate in the city. The author also discusses how knowledge about the favelas has been perceived and constructed throughout the twentieth century, and how a negative image of these communities, 
associating the place and its people with poverty, dirt and trickery, has been forged. Silva stresses that favelas are often studied under two different approaches: "one that intends to formulate 'solutions' to the 'social problems' in the communities and another that seeks to generate political and ideological lines of action" (Silva 2011, 699). However, favela dwellers are not a homogeneous population (see, e.g. Larkins 2015; Pearlman 2010). Nevertheless, the association between the favela and poverty in Brazil is constructed automatically by most of the Brazilian population, including those who are agents in social assistance programmes.

Residents of the Pavão-Pavãozinho favelas interviewed for this study did not always hold the perception that being a resident of the favela was synonymous with being poor, nor that it denoted eligibility for the BFP. This shows a plurality of perceptions and criteria related to the term poverty across and within social groups. Some of these differences can be discerned in the meanings that favela residents attribute to poverty and to being poor.

In the favela, accounts of being poor and of poverty are related to income, but they go beyond it as well. According to one resident, not having a decent bathroom in your house is a sign of extreme poverty. When being invited into private homes in the favela, you often find that the bathrooms only have a toilet and no shower, or that the toilet is broken. Often there is a lack of water. Other homes have bathrooms constructed as outhouses, and many have water containers on the outside of the house. In one of the houses I visited, the woman gave her children baths using a large water container outside the front door. Utilisation of water containers was also reported by Cunha: "these containers are used to store water, as a way for residents to work around the many days that they did not have water in their houses" (Cunha 2011, 16). In some areas, a turn-taking system of water collection known as a "maneuver" is used, consisting of a "local system in which residents redirect the course of water each day to a certain area of the favela, since the public system does not reach all houses" (Cunha 2011, 16, see also Cunha 2014).

By assessing levels of poverty in a concrete fashion by people's relative access to basic services and needs, people in the favelas deploy categorisations of poverty that resembles that of Gutíerrez, who considers poverty as a descriptive category based on comparative indicators vis-à-vis other individuals (Gutíerrez 2007). In that regard, housing issues need to be emphasised as an emic indicator of poverty for residents. For residents of Pavão-Pavãozinho (beneficiaries of BFP or not), the characteristics of houses and their location in the favela indicate who the poor people are. 
Based on observations and the accounts of local residents, it was evident that the poorest families possessed wood houses in the areas with most difficult access and at the highest elevations, known as "Caranguejo" and "Vietnã". In addition to precarious constructions, the access by narrow and steep stairs impeded delivery of purchases and mail. According to Maria, a resident who lived adjacent to "Caranguejo" and who was a beneficiary of the BFP, the closer one lived to "the asphalt", as the formal neighbourhoods are referred to as, ${ }^{11}$ the more expensive the house was:

Poor people like me can't get down; I'm waiting to be called to get a PAC apartment [Programa de Aceleramento do Crescimento, PAC-Program for Growth Acceleration]. Here is an area of risk, so I should go live in the apartments. For now, I'm staying here.

The PAC was created in 2007 during the second term of President Luis Inácio Lula da Silva (see also Sørbøe, this volume, for more on this programme). It aims to resume the planning and execution of social, urban, logistical, and energy infrastructure projects. The housing program $\mathrm{My}$ House, My Life (Minha Casa, Minha Vida) is part of the PAC (www.pac. gov.br) and the programme was also present in Pavão-Pavãozinho. However, since there were not enough new housing units available for all residents living in risk areas, people continued to live in residents that had been marked as dangerous by the Civil Defense.

Another possibility for people living in areas of risk was to be contemplated for a PAC unit in neighbourhoods further away from the south zone (Zona Sul). However, most of the residents preferred to stay in their residences in the south zone. This part of the city was associated with easier access to services (water, electricity, and trash collection), social programmes, proximity to the beach and recreation and sometimes to work and income, in addition to emotional ties. And a resident recounts: “[...] my life is here. I work nearby and I get to the beach easily. I grew up here, how will I get a job if I live far away? I prefer to pay rent and stay here as long as possible". However, residents reported that there has been an increase in the value of housing in recent years—some have already left due to this. A resident, whose family receives the benefit of the BFP, reports that she remains in Pavãozinho because her husband performs odd jobs in the favela, she receives food donations, and the money from BFP helps them to pay the rent (BRL 350.00; EUR 105.46). Their house consists of a single room with bathroom, providing shelter for two adults and five children. The family is extremely poor and also receives help from 
neighbours who donate clothes and milk powder for the children, among other items.

Some people living in the PAC apartements already built by the government in the Cantagalo favela complained about the condominium fee that they need to pay, as this comes at the top of their already heavily strained budgets. Other residents agree with the fee, but they complain that in addition to the buildings there should be parking garage and playground space. According to José, who lives in a government-subsidised apartment, the building lacks automobile parking space for those who own a car as he does.

I lived on the X Street in Pavão; my house was torn down to widen the street. My car is on the other side because I cannot park here. The authorities do not know our reality. There is everything here [in the favela]: poor people and the new middle class (C class) like me. Aren't they talking about the Class $C$ on television? Well, I purchased my used car with a lot of sacrifice, but I bave no parking space for it. In the government's opinion, everybody is poor and has no money to buy a car in the favela. Those who live in the favela must ride a bus or walk.

The difference between the poor and those who are a little better off also involves the ownership of certain assets, such as a car. However, household size - and more specifically the number of people in the household-is a strong indicator of poverty. Added to this, there is the difficulty of continuing living in the favela since there has been a steep increase in the value of housing and rents in Rio de Janeiro, mostly due to the hosting of the 2014 FIFA World Cup and 2016 Olympics (see Sørbøe (Chap. 5) and Ystanes (Chap. 4), this volume, for more on the effects of mega-event hosting in Rio). It is evident from the reports (of beneficiaries and non-beneficiaries) that the poorest have more difficulty in continuing to live in the south zone because of these processes. Thus, two parallel processes have been taking place: on the one hand, the poorest residents have seen their situation improved by the Bolsa Familia cash transfers, and on the other hand, life in south-zone favelas has become increasingly expensive as gentrification takes hold, forcing many of the poorest to leave for less attractive locations. The hosting of mega-events therefore highlights the fragility of the gains in social welfare achieved by the Workers' Party governments, putting the structural and political dimensions of the favela residents housing situations into sharp relief. Harvey (2004), in his analyses of Baltimore, the United States, reports on similar processes in relation to large-scale urban 
development processes, generating a "fever of construction" "no matter what", a shift from the centre to the suburbs, and unordered growth, inequality, and poverty (Harvey 2004, 9-10). This in turn led to an urban crisis. Harvey (2004) illustrates how space comes to be perceived of as capital's material resource, and he highlights the dispersal of manufacturing from centres to suburbs, multinationals' interests, and fiscal austerity as some of the causes of the urban crisis in Baltimore.

In contrast to this perception of space as an asset to be exploited by capital, Lefebvre (2001) points out that space is something that people creates. He emphasises man as the subject of history, who not only reproduces but also produces his and her surroundings. As previously mentioned, local protection network makes it difficult for people to move to a new home distant from the present one (whether or not beneficiaries of Bolsa Familia), even when they live in dangerous circumstances. According to Lefebvre (2001), social relationships are not uniform in time and space; they depend on the reality to which they are subjected. In this sense, the author suggests that space contains the social relations and is a product of them; therefore, reality is historically constructed, which involves having a mental representation of the city and the urban as their material expression. He also points out that a locality is a set of differences, that is, the point of coexistence of plurality and simultaneity of patterns and the different ways of living the urban life. However, space is also a place of conflict, in which exploitation is not particular to the "working class but is found among all social categories" (Lefebvre 2001, 138).

In the Pavão-Pavãozinho favelas, families are distinguished by income level, assets, and the level of education (participation in higher education is considered a milestone). These differences are evidently also found in other communities and populations, favelas or not. However, it is important to highlight these dimensions of favela realities in order to counteract reifying and simplistic perceptions of the favela as a homogenous space of uniform (poor) material and human conditions. Silva (2011) describes the existence of a "favela bourgeoisie", when referring to access to local resources, both economic, political and material. This heterogenity amongst residents creates different viewpoints, assessment and needs; an issue that became evident in my research as I attended meetings of the residents' association. For example, the demand for a parking space in the favela was a recurrent topic at those meeting. Residents who owned a car complained that spaces used to park cars became prohibited since the Pacifying Police Unit (Unidade de Policia Pacificadora-UPP) was set up in Pavão-Pavãozinho. 
The residents justify this claim by saying that the favela has changed and that its residents now have cars. Jussara, a nurse who works at two different hospitals, said that after purchasing her car, for which she is still paying, it is possible to meet her tight schedule at both hospitals. However, the favela does not have a parking space where she could leave her car. Jussara added that they

\begin{abstract}
"could leave their cars on the ' $X$ ' street before, but it is not allowed now and we have no other option. The available space at the entrance must be used to build a parking space. Many people have a car here. They [referring to the Municipality of Rio de Janeiro] think that everyone is poor and that no one has a car here; we have to have the same rights as those who own a house on the 'asphalt'".
\end{abstract}

At another meeting of the residents' association, waste disposal was discussed as the highest ranking priority. Waste and rubbish is found spread on the slopes across the favela and many people tend to blame "the others" for this situation, especially the poorest who are living in the high part of the favela. However, evidently, the most fundamental cause for the waste situation is the deficiencies in basic public services for garbage disposal in the favela.

Another demand was the expansion and improvement of the local family care clinic (a health centre serving the communities of Pavão-Pavãozinho, Cantagalo and adjacent places). According to residents who attended the meeting, the attendance at the family clinic should include sex education, as the number of pregnant adolescents in the community was noticeable. One of the residents agreed with the initiative; however, she emphasised that there is a lot of information about contraceptive methods nowadays, and that pregnancy is in fact a way to get more money from Bolsa Familia. "These girls do not want to study and work, the government pays the stipend. So they get pregnant in order to receive more money. This is poor people's behaviour; they are used to get everything for free", she claimed. Her statement, in spite of being from a favela herself, echoes that of the middle- and upper classes' view on the poor as being lazy, cunning and feeding off the state, illustrating how deeply rooted these imageries are in the Brazilian public.

The per capita income in favelas in the south zone of Rio is higher than the maximum income elegibility criteria established by the BFP. As a consequence, the number of families receiving the benefit is lower that in other favelas in the north and west zone. This led many favela residents to believe that only the poorest people of the favela recieve the benefit of the BFP. Consequently, this perception fuelled a certain stigma of poverty associated with being a BFP beneficiary, as local residents attributed it to being very poor to the extent of struggling to afford food and being dependent 
upon food donations. "Only very poor people have difficulties satisfying their basic needs", said Jonas, a resident of Pavão-Pavãozinho. This view was shared by many of the social workers who work for Bolsa Familia; that is, that access to conditional cash transfer programmes should primarily be destined to those facing difficulties in obtaining food. ${ }^{12}$ However, this perception did not imply that the social workers did not recognise that other households benefiting from the programme also needed the money. Indeed, the also displayed "solidarity" with the beneficiaries that exceeded the stipulated maximum income of BRL 170.00. During the research, cases arose when the family had an increase in income exceeding the maximum level, prompting the social worker to suggest that the beneficiaries should provide that information at a later point in order to be able to continue receiving the stipend until the deadline for the re-registration process. This reflects that in the social workers' opinion, who became well aware of the everyday life realities of living in poverty, the meanings of poverty are not based solely on per capita income established by the programme. These meanings are also based on the story of each family in a detailed case report. Thus, sometimes learning about people's family histories made it possible for social workers to take a multidimensional approach to the concept of poverty beyond the strictly monetary criteria established by the programme.

Another variable described by residents and beneficiaries as poverty indicator relates to not having at least one stable source of income in the family, because "guaranteed money helps a lot, it is financial security" in difficult times (see, e.g. Lavra Pinto 2013). According to Maria Claudia, life was different when her husband had a permanent job. "The Bolsa Familia benefit is our only income, but it is not enough. I pray he will soon find a formal job because depending on the BFP is much humiliation." Aparecida, another beneficiary also reports on the precariousness in which the family lives and the lack of formal work:

\section{I do not like to receive BF: It's humiliating. Our lives are being watched, no one likes that. If I had studied I would be a public servant [...]. Money in the bank, monthly salary to buy what my kids ask for [...]. Wow, it would be awesome!}

Even with these differences in income and access to goods and services, the fact of being a favela resident qualifies the "applicant" to access the BFP registration. For example, the information that a person resides in a favela allows him/her to see the social workers working for the programme, and if the income is within the criteria established by law, this person will eventually be registered in the programme. The relationship between poverty 
and favela is generated almost automatically by those who work for the BFP. In many ways, their conceptualisation of the favelas they work in has not caught up with the profound changes in standard of living that many favela residents have seen during the Pink Tide. Interestingly, favela residents sometimes question the notion of poverty based on income, as applied by the programme. ${ }^{13}$ For example, there are stories circulating about people who request the benefit although they are not in need of it. According to a beneficiary of Pavão-Pavãozinho, her neighbour draw monthly benefits from the BFP, but she does not need it because "she owns her home, her husband works and she is retired". About her own situation, however, she notes:

I do deserve it, because I have no formal job and I pay rent, I am poor, but not miserable; food is not missing, but without the benefit it would be difficult to pay the electricity bill [now that the 'cat'-illegal electricity connection-is over], and other bills.

Thus, she does not question low income as a criterion, but invokes dimensions she also thinks should be included in the evaluation of a person's poverty; homeownership, the income of others in the household, access to informal solutions and age. Another beneficiary reports the same as her neighbour: a woman she knows does not need the money because she "has money in the bank and pays health insurance $[\ldots]$ ". About her own situation, she notes: "I am so poor, I have only the BF benefit and if I get sick, I use the public health system". These statements are recurrent. In some cases, social workers visit the homes of beneficiaries to check the "actual" family conditions.

In many ways, the concept of assistance that beneficiaries are suggesting, and that social workers are sometimes providing, is similar to the socialistera Hungarian system described by Haney (2000). Here, beneficiaries could appeal to a whole range of issues that social workers could help them address, and a lack of money was just one of them. Domestic violence, strained kinship or marital relations, neglect and work-related problems were all issues for which people could receive the assistance of social workers. Later, as neoliberal reforms were introduced and welfare became based on a strict assessment of economic need, the concept of poverty, and of need, narrowed. Similarly, the ethnographic material presented here shows that while access to the BFP is granted based on an assessment of economic need, beneficiaries as well as social workers often have a more multidimensional understanding of poverty. They might agree with Simmel (1998), 
who argues that in sociological terms, poverty refers less to people with low income and more to individuals who are dependent on assistance. For him, poor people are not those who have specific needs or privations, but those who receive assistance or should receive it.

For residents in Pavão-Pavãozinho, the lack of a formal source of income, difficulty to buy food, the receipt of BF (or other federal, state, or municipal benefit), and the type and location of the house in the favela are indicators of whether families and individuals are considered as "poor". These representations and definitions are multidimensional, and it is important to point out that the comparisons are made between the residents themselves (whether they are beneficiaries or not). Surely, if the comparison were made with the inhabitants of the "asphalt" (middle-class residents of nearby neighbourhoods), all the favela residents would be considered "poor".

\section{Final Considerations: Bolsa Familia AND THE Pink Tide}

The insights about the dynamics guiding the BFP offered in this chapter, provides a glimpse of its role in reducing poverty and inequality in Brazil during the Pink Tide period. It is estimated that the programme has contributed to bringing 36 million people out of the extreme poverty. According to the Human Development Index (HDI), it points to the growth of the Brazilian HDI, from 0.683 in 2000 to 0.755 in 2014, a rise of more than 10.5 per cent (Human Development Report 2014). The contributions of BFP in achieving these improvements is evident in guaranteeing a minimum income to families in poverty, and in strengthening the capacity of people to invest in schooling and in the healthcare of children through conditionalities.

Although the research period (2012-2015) has not covered the current political moment, it is worth mentioning that the future of the BFP is uncertain. The neoliberal orientation of the government of President Michel Temer, indicates that the programme will be revised. However it is not yet known what exactly will be changed. However, beneficiaries are currently reporting increasing difficulties in accessing the benefits and that families have also stopped receiving it. At the current moment in Brazil, the Bolsa Familia programme is on the threshold between the achievements of the Pink Tide period and the return to power of a party that tries to implement neoliberal measures. 


\section{Notes}

1. The Favelas of Pavão-Pavãozinho are located in the neighbourhood of Copacabana. They have a population of 5567 inhabitants distributed in 1840 households.

2. According to Naomi Klein (2007), neoliberal ideas started to be implemented in Brazil as early as after the coup in 1964, and much of the economic policy of the military regime was designed by economists educated under Milton Friedman in Chicago.

3. In the 2006 presidential election between Geraldo Alckmin (PSDB) and Luiz Inácio Lula da Silva (PT), Lula was elected in the runoff with 60.83 per cent of the votes (TSE 2006). For an analysis of the electoral result, see for example Holzhacker and Balbachevsky (2007).

4. The Bolsa Familia allowances are updated for 2016, following the increase in July 2016.

5. Under the Michel Temer government, after June 2016 the Ministério de Desenvolvimento Social e Combate à Fome (Ministry of Social Development and Fight Against Hunger) became the Ministério de Desenvolvimento Social e Agrário (Ministry of Social and Agrarian Development), and then renamed to Ministério de Desenvolvimento Social (Ministry of Social Development).

6. The numbers referring to the BFP change every month, since families enter and leave the programme for various reasons. However, the total amount of beneficiary families has remained around 13 million (MDS 2016).

7. Data from CRAS São Sebastião, 2015.

8. It should be noted that pregnant women are identified by the local health service they belong to and sent to the BFP.

9. Payment is made in six consecutive monthly instalments, provided that the child has been identified in the Cadastro Unico (Single Registration) up to the sixth month of life.

10. The CPF has 11 numbers and serves as a credit identifier, through which it is possible to check debts (if any) of the user with any company, in addition to being requested in numerous places where it is necessary to prove identity.

11. The term "asphalt" is used as favela residents use it, to denote Zona Sul residents who do not live in the favela, even if they live in close proximity.

12. According to a report from the Brazilian Institute for Social and Economic Analysis (IBASE 2008), beneficiary households of the BFP have consumed more animal and dairy products, cookies, oil, sugar, and processed foods (see, e.g. Lavra Pinto and Pacheco 2009).

13. The applicant who does not have a proof of earned income must fill in and sign a declaration that informs about the number of people in the household and per capita income. 


\section{REFERENCES}

Anderson, David M., and Vigdis Broch-Due. 1999. The Poor Are Not Us. Poverty \& Pastoralism in Eastern Africa. Oxford/Nairobi/Athens: James Currey/ E.A.E.P./Ohio University Press.

Broch-Due, Vigdis, and Richard A. Schroeder. 2000. Producing Nature and Poverty in Africa. Stockholm: Nordiska Afrikainstituttet.

Cunha, Juliana B. 2011. O PAC e a UPP no complexo Pavão-PavãozinhoCantagalo: processo de implementação de políticas públicas em uma favela da zona sul da cidade do Rio de Janeiro. In XI Congresso Luso Afro Brasileiro de Ciências Sociais. Salvador. https://www.file:///E:/1308347052_ARQUIVO_ paperConlab.pdf. Accessed Mar 2016.

- 2014. "Nossa casaca é dupla-face": dinâmica sócio espacial e política local no processo de implementação do PAC e da UPP em uma favela da cidade do Rio de Janeiro. São Paulo: Tese Doutorado em Antropologia Social - Universidade de São Paulo.

DaMatta, Roberto. 1995. On the Brasilian Urban Poor: An Anthropological Report. Kellog Institute, Democracy and Social Policy Series, Working Paper.

Desrosieres, Alain. 2010. Est-il bom, est-il méchant? Le role Du nombre dans Le gouvernement de La cite néolibérale. Comuunication au Seminaire L'informazione prima dell'informazione. Conoscenza e Scelte Pubbliche, Univerwsite de Milan Bicocca.

Gutiérrez, Alicia. 2007. Pobre como sempre: estratégias de reprodução social da pobreza. Córdoba: Ferreira Editor.

Haney, Lynne. 2000. Global Discourses of Need: Mythologizing and Pathologizing Welfare in Hungary. In Global Ethnography: Forces, Connections, and Imaginations in a Postmodern World, ed. Michael Burawoy et al. Berkeley/Los Angeles/London: University of California Press.

Harvey, David. 2004. Os espaços de utopia. In Espaços de Esperança. São Paulo: Edições Loyola.

Hoffman, Rodolfo. 2006. Transferência de renda e a redução da desigualdade e da pobreza. In Revista Parcerias estratégicas/CGEE. Brasília, 22 (6).

Holzhacker, Denilde Oliveira, and Elisabeth e Balbachevsky. 2007. Classe ideologia e política: uma interpretação dos resultados das eleições de 2002 e 2006. Opinião Pública 13 (2).

IBASE. 2008. Relatório Repercussões do Programa Bolsa Familia na Segurança Alimentar e Nutricional das Familias Beneficiadas. Documento síntese, Junho 2008. Rio de Janeiro: Instituto Brasileiro de Análises Sociais e Econômicas. http://www.ibase.br/userimages/ibase_bf_sintese_site.pdf. Accessed October $3,2017$.

Instituto Brasileiro de Geografia e Estatística (IBGE). 2015. Estimativa da população 2015. Accessed 15 Dec 2016. 
Instituto de Pesquisa Econômica Aplicada (IPEA). 2010. O Brasil em 4 Décadas. Brasília: Ipea.

Jaccoud, Luciana. 2006. Indigência e Pobreza: efeitos dos benefícios previdenciários, assistenciais e de transferência de renda. In Desafios e Perspectivas da Política Social, ed. Anna Maria T. Medeiros Peliano. IPEA: textos para discussão, (1248). https://www.cebes.org.br/anexos/desafios\%20E\%20perspectivas\%20 da\%politicasocial.pdf. Accessed Aug 2009.

Klein, Naomi. 2007. The Shock Doctrine: The Rise of Disaster Capitalism, 80-81. London/New York: Penguin.

Lahóz, André. 2002. Renda e Consumo. In A era FHC, um balanço, ed. Bolíver Lamounier and Rubens Figueiredo. Cultura Ed: São Paulo.

Larkins, Erika Mary Robb. 2015. The Spectacular Favela: Violence in Modern Brazil. Oakland: University of California Press.

Lautier, Bruno 2002. Pourquoi faut-il aider les pauvres? Une étude critique Du discours de La Banque mondiale sur La pauvreté. Revue Tiers Monde, T. XLIII, (169), janvier-mars.

Lavra Pinto, Michele de. 2013. O público e o privado: o ‘baralhamento' no cotidiano das famílias beneficiárias do Programa Bolsa Família. Politica é Trabalho. Revista de Ciências Sociais 38 (4).

Lavra Pinto, Michele de, and Janie K. Pacheco. 2009. Consumo, moralidade e o Programa Bolsa Família: padrões e percepções de um grupo de baixa renda. In Juventude, Consumo \& Educação 2, ed. Michele de Lavra Pinto and Janie K. Pacheco. ESPM: Porto Alegre.

Lefebvre, Henri. 2001. O direito à cidade. São Paulo: Centauro.

Magalhães, Alexandre de. 2013. Transformações no "problema favela” e a reatualização da "remoção" no Rio de Janeiro. Centro de Ciências Sociais. Instituto de Estudos Sociais e Políticos. UERJ.

Milton, Cynthia E. 2007. The Many Meanings of Poverty. Colonialism, Social Compacts, and Assistance in Eighteenth-Century Ecuador. Stanford: Stanford University Press.

Ministério de Desenvolvimento Social e Combate à Fome. 2015. Relatório do Bolsa Familia Rio de Janeiro. http://www.mds.gov.br/. Accessed Nov 2015.

- 2016. Relatório do Bolsa Familia. http://www.mds.gov.br/. Accessed Dec 2016.

- 2017. Relatório do Bolsa Familia Rio de Janeiro. http://www.mds.gov. br/. Accessed Feb 2017.

Neder, Henrique Dantas. 2006. Indicadores sociais no Brasil: uma análise de sua evolução em período recente. Revista Parcerias estratégicas, Brasília 22 (6).

Neri, Marcelo. 2010. CPSéEPGE. https://www.fgv.br/cps. Accessed 20 Dec 2012.

. (ed.) 2011. Miséria, Desigualdade e Estabilidade: o segundo real. Rio de Janeiro: CPS/FGV. https://www.fgv.br/cps/pesquisas. Accessed $28 \mathrm{Sept}$ 2011. 
O’Connor, Alice. 2002. Poverty Knowledge: Social Science, Social Polity, and the Poor in Twentieth-Century U.S. History. Princeton: Princeton University Press. Pearlman, Janice. 2010. Favela. Four Decades of Living on the Edge in Rio de Janeiro. Oxford: Oxford University Press.

Peres, Thais Helena de Alcântara. 2005. A proposta de um outro modelo para as políticas sociais. Civitas Revista de Ciências Sociais, Porto Alegre 5, n. 1 (2).

Pires, André, and Tainah Biela Dias. 2015. De Bolsa Esmola à Constituição Federal: o Programa Bolsa Família no jornal O Estado de São Paulo (2003-2013). Fronteiras - estudos midiáticos 17 (2).

Rattner, Heinrich. 2010. Como medir e combater a pobreza? Revista Espaço Acadêmico 112 (9).

Rego, Walquiria L., and Alessandro Pinzani. 2013. Vozes do Bolsa família: autonomia, dinheiro e cidadania. São Paulo: Unesp.

Reis, Elisa P. 2005. Pobreza e Exclusão. In Exclusão Social e Mobilidade no Brasil, ed. Estanislao Gacitúa-Marió and Michael Woolcock. Brasília: IPEA/Banco Mundial.

Relatório Repercussões do Programa Bolsa Família na Segurança Alimentar e Nutricional das Famílias Beneficiadas. 2008. Documento sintese (6). https:// www.ibase.br. Accessed 14 Aug 2010.

Rocha, Sonia Maria Rodrigues da. 2007. Pobreza no Brasil: afinal, de que se trata? Rio de Janeiro: Ed. FGV.

Sen, Amartya. 2000. Desenvolvimento como liberdade. São Paulo: Cia das Letras.

Silva, Luiz Antônio Machado da. 2011. A política das favelas. In Revista de Estudos de Conflitos e Controle Social 4 (4), out/nov/dez.

Silva, Maria Ozanira da Silva e, and Valeria Ferreira Santos de Almada Lima. 2010. Avaliando o Bolsa Família: unificação, focalização e impactos. São Paulo: Cortez.

Silva, Maria Ozanira da Silva e, et al. 2008. A politica social brasileira no século XXI: a prevalência dos programas de transferência de renda. $4^{\mathrm{a}}$ ed. São Paulo: Cortez.

Simmel, Georg. 1998. Les pauvres. Paris: Press Universitaires France.

Sprandel, Marcia A. 2004. A pobreza no paraiso tropical: interpretações e discursos sobre o Brasil. Rio de Janeiro: Relume Dumará.

Tribunal Superior Eleitoral. 2006. www.tse.jus.br/eleicoes/. Accessed 15 Mar 2016.

Valladares, Licia do P. 2000. A gênese da Favela Carioca. A produção anterior às Ciências Sociais. RBCS 15 (10).

- 2005. A invenção da favela. Rio de Janeiro: FGV.

Weissheimer, Marco Aurélio. 2006. Bolsa Familia: avanços, limites e possibilidades do programa que está transformando a vida de milhões de familias no Brasil. São Paulo: Editora Perseu Abramo. 
Open Access This chapter is licensed under the terms of the Creative Commons Attribution 4.0 International License (http://creativecommons.org/licenses/ by $/ 4.0 /$ ), which permits use, sharing, adaptation, distribution and reproduction in any medium or format, as long as you give appropriate credit to the original author(s) and the source, provide a link to the Creative Commons license and indicate if changes were made.

The images or other third party material in this chapter are included in the chapter's Creative Commons license, unless indicated otherwise in a credit line to the material. If material is not included in the chapter's Creative Commons license and your intended use is not permitted by statutory regulation or exceeds the permitted use, you will need to obtain permission directly from the copyright holder.

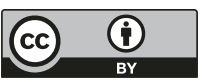

